\title{
原著冷え症に対する鍼冬治療の臨床的研究（第| 報）
}

\author{
根本 宏三* 水上守 丹沢章八
}

要旨われわれは，何らかの基礎疾患をもち，かづ手足の冷え”を主 訴とする21例の冷之症患者を対象に鍼尒治療を行い, 初診時と10回目 の治療時とで自他覚所見を比較検討した。

その結果，(1)自覚的には，手足の冷えに対し有効率は $55.9 \%$ で，冷 之の改善とともに随伴症状も緩解した。(2)一般的に冷之症は健常者に 比し, 下腿部から足部にかけて皮膚温が低く, しかも主訴に合致した 身体部位に皮膚温の低下が認められた。(3)鍼尒刺激は，末梢循環動態 に強い影響を及ぼすことから，銊炎治療は自覚的な冷えの改善に対し 有効な治療手段の一つと言える。

\section{I はじめに}

冷え症に対する病名としての定義には明確なも のはない。しかし症候(自覚症状)として，その改 善を期待して銊尒外来を訪れる人は意外に多い。 したがって銊尒臨床の現場では，古くから日常し ばしば遭遇する症候の一つとして扱われてきたし， また数多くの治験報告が見られる ${ }^{1 \sim 5)}$ 。今回われわ れは，何らかの基礎疾患をもち，そのうえに゙手足 の冷え”を強く訴える冷之症患者に銊尒治療を行な い, 初診時と 10 回目の治療時とで自覚症状と他覚 症状(主として血圧, 皮虐血管反射から見た自律神 経系機能)を比較検討した結果, 興味ある知見を得 たので報告する。

\section{II 対象と方法}

対象は，表 1 に示す七沢リハビリテーション病 院・東洋医学科(以下当科と略す。) に昭和 62 年 9 月

\section{*Kouzou Nemoto 七沢リハビリテーション病院 東洋医 学科}

共同研究者：Mamoru MizuKami, Shohhachi TANZAWA 七沢リハビリテーション病院 東洋医学科

Key Words : 冷之症, 鍼炎治療, 皮虙温, サーモグラフィ
から12月までの期間中に来診しだ手足の冷え゙を 主訴とする 21 例である。男性は 9 名 $(42.9 \%)$ ，女 性 12 名 $(57.1 \%)$, 平均年㱓は 58.0 歳, 罹患年数は ほとんどが $1 \sim 2$ 年前後で, 冷之症患者には, 肩 凝り・便秘・倦怠感・不眠・腰痛など多彩な随伴 症状が認められた。当院は, 脳血管障害後遺症の リハビリテーション専門病院であるので，基礎疾 患としては対象患者の中の 13 名 $(61.9 \%)$ が脳卒中 後遺症患者であることが特徵であり，また脳卒中 以外の 8 名の対象患者は, 動脈閉塞を伴う血管炎 による循環障害患者 1 名 $(4.8 \%)$ ，骨の変形や椎間 板に起因する神経圧迫所見を有するもの3名(14.3 $\%)$, 更年期障害者 4 名 (19.0\%)で対象患者のすべ てに何らかの基礎疾患が認められた。

治療方法は循環機能の活性化と全身的な変調効 果を目的とした本治・標治を交えた鍼炎治療を週 2 回行なった。鍼治療は, 膻中・中脘・肓俞・関

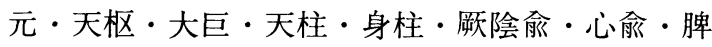

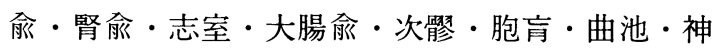
門，陰陵泉，太箕などの経穴に対し，ステンレス 鍼40ミリメートル20号鍼を用い単刺術・雀啄術・ 置鍼術を中心とした普通鍼を行ない，併せて郄門 と内関，足三里と三陰交を結びパルス通電刺激を $1 \mathrm{~Hz}, 30$ 分間行なった。また，尒治療は，腎俞・ 
表 1 患者リスト

\begin{tabular}{|c|c|c|c|c|c|c|c|c|c|}
\hline No. & 患者名 & 生用 & 年 & 診 & 断 & 名 & 罹患年数 & 訴 & 随 伴 症 状 \\
\hline 1 & T. Y. & 男 & 53 & 脳 & 血 & 栓 & $1 \mathrm{y} 10 \mathrm{~m}$ & 手足冷 腰痛 & 肩こり 左上下肢のしびれ \\
\hline 2 & $\mathrm{~K} . \mathrm{K}$. & 男 & 46 & 脳 & 出 & 血 & $2 y 9 m$ & 足冷 耳鳴 & 肩こり 左上下肢のしびれ 倦息感 めまい \\
\hline 3 & K. Y. & 男 & 67 & 脸 & 梗 & 塞 & $12 \mathrm{y}$ & 手足冷 & 右上下肢のしびれ 下肢痛 \\
\hline 4 & T. S. & 男 & 67 & バーシ & シャー & - 病 & $2 y$ & 手足冷 & 下肢痛 腰痛 \\
\hline 5 & O. Y. & 女 & 72 & スモ & Eン病 & & $18 y$ & 足冷 下麻 & 下肢のしびれ 肩こり 腰痛 倦息感 不眠 \\
\hline 6 & K. T. & 女 & 68 & 変形性 & 尘脊椎 & & $30 y$ & 足冷 & 肩こり 腰痛·㮏痛 \\
\hline 7 & i. $\mathrm{k}$. & 男 & 38 & 椎間板 & 反へヘル & レニア & $1 \mathrm{~m}$ & 足冷 腰痛 & 倦总感 左下肢痛 \\
\hline 8 & Y. S. & 女 & 42 & 自律神 & 申経失 & 大調症 & $15 y$ & 足冷 & 肩こり 腰痛 倦急感 便秘 \\
\hline 9 & S. M. & 女 & 25 & 自律神 & 申経失 & 夫調症 & $2 y$ & 足冷 & 肩こり 腰痛 倦急感 便秘 \\
\hline 10 & K. Y. & 女 & 54 & 自律神 & 申経失 & 夫調症 & $9 y$ & 足冷 便秘 & 肩こり 腰痛 肩痛 \\
\hline 11 & T. M. & 女 & 71 & 自律神 & 申経失 & 夫調症 & $3 y 3 m$ & 手足冷 & 肩こり 倦急感 不眠 便秘 \\
\hline 12 & S. Y. & 男 & 51 & & 梗 & 塞 & $1 \mathrm{y} 6 \mathrm{~m}$ & 足冷 & 肩こり 上下肢のしびれ 不眠 頭痛 背痛 \\
\hline 13 & A. M. & 女 & 49 & 脸 & 出 & 血 & $1 \mathrm{y} 8 \mathrm{~m}$ & 足冷 & 肩こり 腰痛 便秘 下肢のしびれ 背痛 \\
\hline 14 & S. Y. & 女 & 64 & 脳 & 梗 & 塞 & $1 \mathrm{y} 4 \mathrm{~m}$ & 足冷 肩痛 & 肩こり 便秘 不眠 頭痛 \\
\hline 15 & S. K. & 女 & 82 & 睬 & 梗 & 塞 & 2 y $9 \mathrm{~m}$ & 手足冷 肩痛 & 倦急感 便秘 \\
\hline 16 & O. S. & 男 & 58 & 脳 & 出 & 血 & $2 y$ & 手足冷 肩痛 & 肩こり 便秘 倦息感 頭痛 \\
\hline 17 & N. S. & 女 & 67 & 脳 & 出 & 血 & 1 y $5 \mathrm{~m}$ & 手足冷 肩痛 & 腰痛 便秘 不眠 \\
\hline 18 & I. M. & 男 & 69 & 脳 & 出 & 血 & $3 y$ & 手足冷 肩痛 & 肩こり 倦息感 便秘 不眠 \\
\hline 19 & $\mathrm{~T} . \mathrm{T}$. & 女 & 51 & 脳 & 出 & 血 & 2 y $8 \mathrm{~m}$ & 手足冷 肩痛 & 肩こり 倦意感 便秘 不眠 \\
\hline 20 & K. N. & 男 & 65 & 蝺 & 梗 & 塞 & $4 \mathrm{~m}$ & 足冷 肩痛 & 倦急感 腰痛 不眠 \\
\hline 21 & S. H. & 女 & 59 & 兴 & 出 & 血 & $9 \mathrm{~m}$ & 足冷 肩痛 & 屃こり 上肢のしびれ 不眠 \\
\hline
\end{tabular}

足三里・復溜・涌泉の経穴に対してカマヤミ二炎 を 2 壮施尒した。効果の判定は, 当科で作成した 自他覚症状の評価表を用い自覚症状は，とても気 になってがまんできない $(3+)$ ，気になるががま んできる $(2+)$ ， あるがさほど気にならない(+), よくわからない $( \pm)$, ない $(-)$ の 5 段階評価を, 他覚所見は, かなり認める $(2+)$, 認める $(+)$, やや認める $( \pm)$, なし $(-) の 4$ 段階評価を行ない, ほかに血圧変動係数, サーモグラム, 臨床心理テ ストを指標とした。なお治療成績は，自他覚所見 の症状消去率 $80 \%$ 以上を著効，80\%未満60\%以上 を有効， 60\%未満 $40 \%$ 以上をやや有効， $40 \%$ 未満 を不変として評価した。

\section{III 結果と考察}

著効十有効を鍼尒治療有効群, やや有効十不変 を鍼尒治療無効群とすると，表 2 のごとく自覚的 には，手足の冷えに対し鍼炎治療の有効率は55.9 \%で，冷えの改善とともに，肩凝り・全身倦㤐感 ・便秘などの随伴症状が改善し, 腹証にも顕著な
変化が認められた。

図 1 は臥位時最高血圧と立位時最高血圧より求 めた血圧変動係数(係数值 0.12 以上を自律神経機能 不安定值とするため点線で挟まれた領域は自律神 経機能安定域を示し, それ以外の領域は不安定域 を示す。をを現わしたものである。図 1 から自・他 覚所見の症状消去率 $60 \%$ 以上にあたる鍼尒治療有 効群の血圧変動係数は, 鍼炎治療無効群と異なり, 10 回目の治療時には，ほとんど自律神経機能安定 域に入るという結果が得られた。また，臨床心理 テスト (C.M.I. 深町変法・阿部変法・M.A.S. テス ト)の成績を初診時と治療10回目とで比較した結果, 銊炎治療有効群は，治療10回目には正常領域に入 ク，心理面での改善も認められた。以上の成績か ら, 自覚症状改善群は他覚的にも指標全般に改善 が認められることがわかった。なおサーモグラム で改善の経過を追跡した結果は以下のとおりであ $3^{6 \sim 9)}$ 。

体幹部における健常者と冷之症との皮覤温分布 を比較した結果，図 2 のように冷え症の下腹部は 
表2 治療効果

\begin{tabular}{|c|c|c|c|c|}
\hline \multirow{2}{*}{ 所見 } & \multicolumn{2}{|c|}{ 鋮炎治療有奻群 } & \multicolumn{2}{|c|}{ 鋮炎治療無効群 } \\
\hline & 著 効 (人) & 有 効 (人) & やや有効（人） & 不 変 (人) \\
\hline 主 & \multicolumn{2}{|r|}{$9 \%$} & \multicolumn{2}{|c|}{$44.1 \%$} \\
\hline 手の冷之 (13) & $23.1 \%(3)$ & $38.4 \%(5$ & $23.1 \%(3)$ & $15.4 \%(2)$ \\
\hline 足の冷之 (21) & 14.3 & 38.1 & 28.6 & 19.0 \\
\hline 不定愁訴 & \multicolumn{2}{|c|}{$55.8 \%$} & \multicolumn{2}{|c|}{$47.5 \%$} \\
\hline 倦急感 (14) & 7. $1 \%(1)$ & $50.9 \%(1)$ & $35.8 \%(5)$ & $7.1 \%(1)$ \\
\hline 不 眠 (12) & 16.7 & 41.7 & 33.3 & 8. 3 \\
\hline 局凝り (17) & 11.8 & 41.1 & 17.7 & 29.4 \\
\hline 腰 痛 (11) & 18.2 & 36.4 & 18.2 & 27.2 \\
\hline 便 秘 (14) & 14.3 & 42.9 & 28.5 & 14.3 \\
\hline 腹 & \multicolumn{2}{|c|}{$52.5 \%$} & \multicolumn{2}{|c|}{$47.5 \%$} \\
\hline 心下㾂硬 (20) & $25.0 \%(5)$ & $25.9 \%(5)$ & $25.0 \%(5)$ & $25.0 \%(5)$ \\
\hline 胸脇苦满 (20) & 20.0 & 30.0 & 35.0 & 15.0 \\
\hline 血(20) & 25.0 & 30.0 & 30.0 & 15. 0 \\
\hline 小腹急結 (20) & 20.0 & 35.0 & 20.0 & 15. 0 \\
\hline 腹皮拘急(21) & 19.0 & 33.4 & 33.4 & 14.2 \\
\hline
\end{tabular}

著 効 ; 症状消去事 $80 \%$ 以上 や队有効；症状消去事 $40 \%$ 以上
(症候別出現事 $50 \%$ 以上)

有 効; 症状消去事 $60 \%$ 以上

不 変; 症状消去率40\%未淦

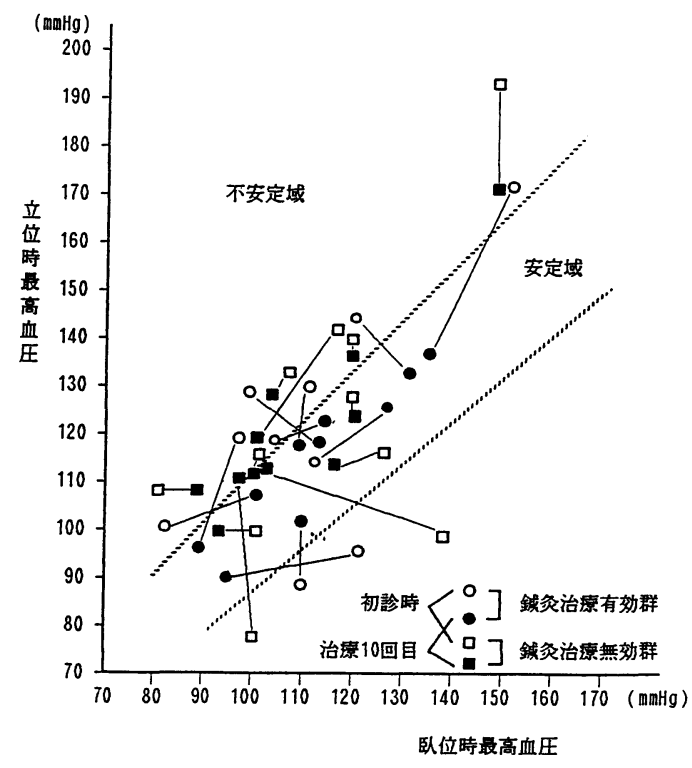

図 1 血圧変動係数

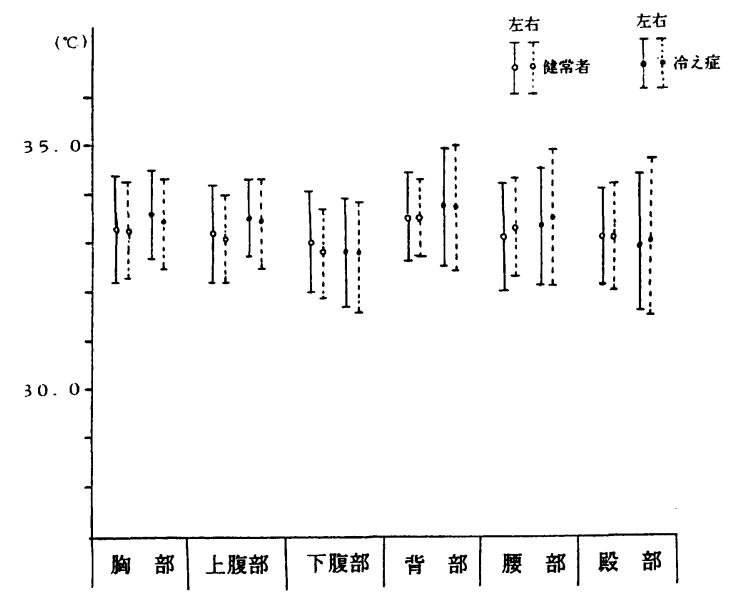

図2 健常者と冷え症との皮虐温の比較(体幹部)

健常者に比べ若干皮膚温が低いことが認められた。 同じく上下肢における健常者と冷え症との皮虑温 分布を比較した結果は, 図 3 のように冷之症は健 常者に比べ下腿部から足部にかけて皮膚温が低く， また上下肢末端になるほど皮膚温のバラツキも大 きくなり健常者のような安定した皮䖉温が認めら れず，しかも主訴に合致した部位に皮膚温の低下 が見られた。 


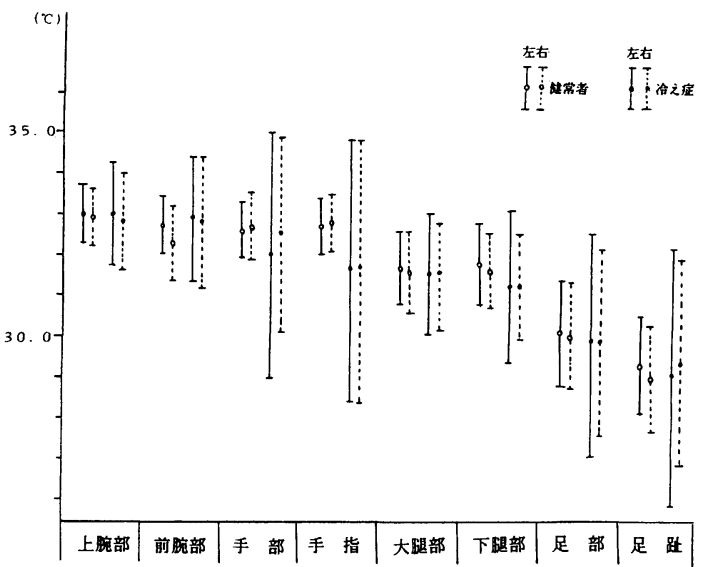

図3健常者と冷え症との皮膚温の比較(上下肢)

体幹部(胸腹部)における皮膚温の変化を鍼炎治 療有効群と無効群とで比較した結果, 図 4 のごと 〈銊炎治療有効群は無効群と異なり，治療回数を 重ねるに従い全身的に皮膚温が上昇して行くこと が観察された。同じく下肢における皮膚温の変化 を鍼炎治療有効群と無効群とで比較した結果, 図 5 のように，下肢では体幹部と同じく全身的に皮 膚温が上昇して行くという結果がさらに著明に認 められた。なおこれらの結果は，背腰殿部と上肢 においても同様の成績が観察できた。以上の結果 から銊炎治療有効群は治療回数を重ねるに従い, 全身的に皮膚温が上昇し，その上昇傾向は四肢末 端ほど強くなる傾向があることがわかった。

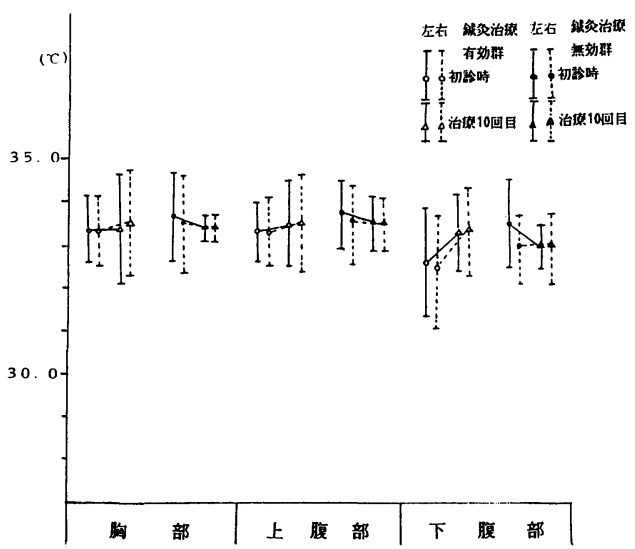

図4 鍼炎治療有効群と鍼炎治療無効群の皮虚温の 比較 (体幹部)

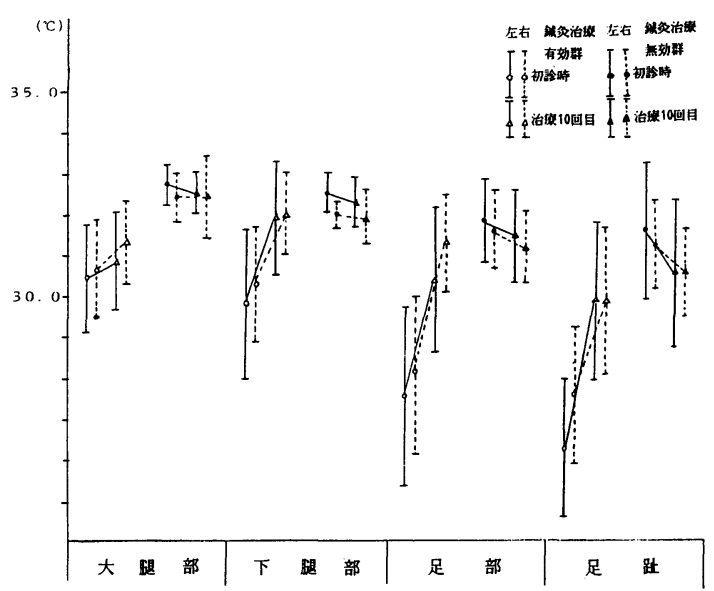

図 5 銊炎治療有効群と鍼炎治療無効群の皮虙温の 比較 (下肢)

図 6 は冷之症の代表例の初診時と治療開始 1 力 月後(治療10回目)における体位変換時の体幹部・ 下肢のサーモグラムである。初診時は，体幹部・ 下肢の皮膚温はともに全体的に低下し，立位負荷 を与えた時に血管反射が悪いためか, 卧位と立位 の全身的な皮膚温に差があるのに対し，1 力月後 には全体的に皮膚温は上昇し, 立位負荷による血 管反射の改善を思わせる結果が得られ，鍼炎治療 有効群は, 治療回数を重ねるに従い, 体位変換に 際して起こる血管反射も並行して改善して行くこ とが確認された。これらの現象は, 鍼尒刺激によ り全身的な自律神経機能が安定化に向かって改善 傾向を示したことを示唆するものと考える。

ところで著者の一人丹沢は, 脳卒中後遺症 $($ 片麻 痺）に対する銊尒治療の一連の臨床研究を通じ ${ }^{10,11)}$, 鍼尒治療は片麻痺患者の麻痺そのものの改善効果 を期待するというよりは，片麻痺のリハビリテー ションの阻害因子となる各種の症候や合併証の改 善に主目的を置き, 片麻痺のリハビリテーション の効果的な補助手段の一つとして活用すべきであ ることを強調してきた。その途次で近年, 片麻痺 患者と, 中枢神経系の障害以外の患者との主とし て鍼炎治療による和痛効果について対比した報告 では ${ }^{12)}$ ，明らかに片麻痺患者の治効率は低いという 成績が得られたことから，中枢神経系の障害者は， それ以外の病態に比べると鍼炎刺激に対する応答 
症例F.Y. 42歳 女（自律神経失調症）

初診 時 臥 位
立 位
1 力月後 (治療10回目)

臥 位

立 位

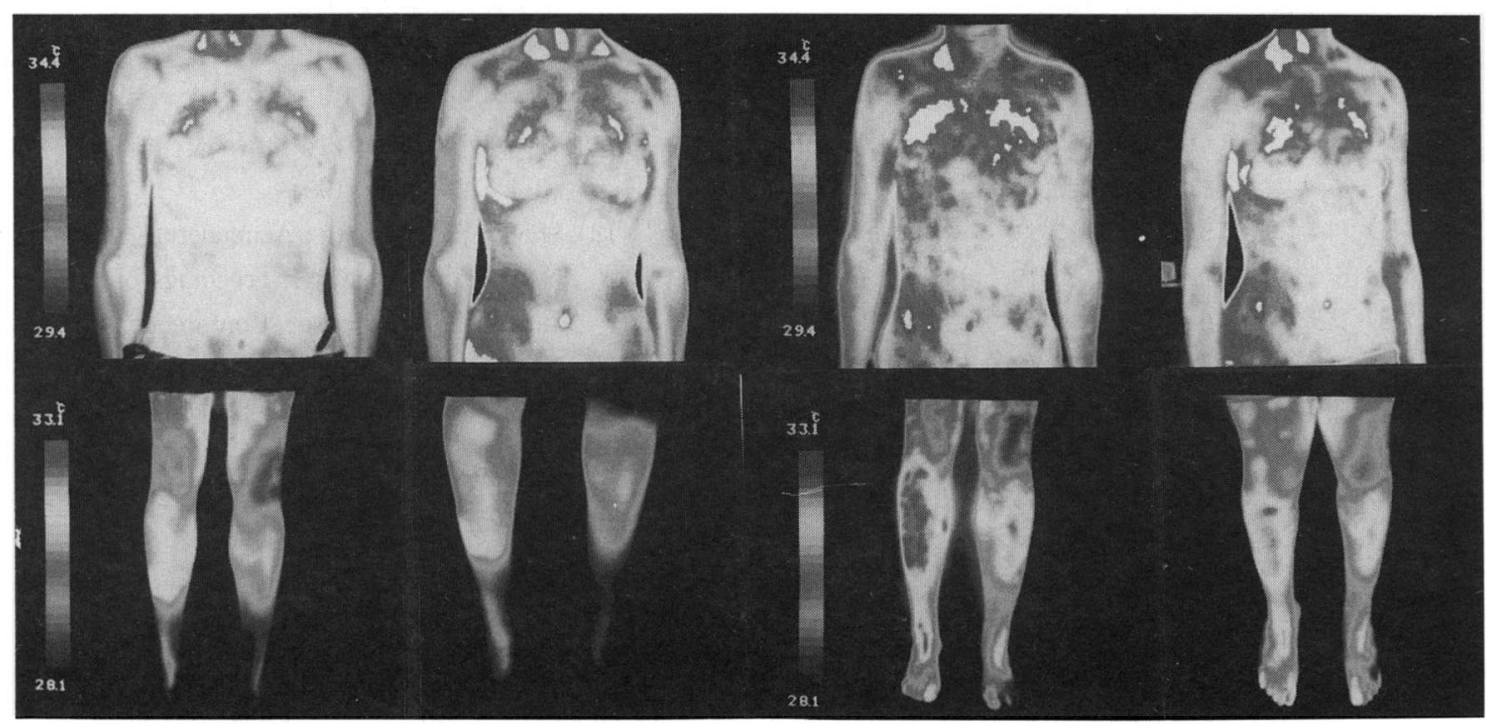

図6 体位変換時における初診時と 1 力月後の 皮膚温の比較(冷え症)

性と反応性が劣るのではないかと推論している。

さて，本報告の対象は，約 $62 \%$ の片麻痺患者を 含む何らかの基礎疾患をもつ対象群であった。そ して治療成績は, 主訴としての゙手足の泠え”の改 善率が約 $56 \%$ という結果であった。この数字は前 述したとおり，“やや有効”を算入していない数值 であるので, 従来みられる報告に比し決して低い ものではない。とすると，本報告の結果にみられ る鍼炎刺激の自律神経系機能に働く調整・安定化 作用は，ある程度の病態の相違を越えて普遍性を もった作用であるのか，それとも和痛効果とは作 用機序が異質であるのか, 現段階ではその間に答 える資料をわれわれはもっていない。その意味で は, 本研究の結果は新たな問題を投げかけるとと もに，われわれにその解答を導き出すよう命題を 与えたことになる。今後はさらにいろいろな基礎 疾患をもつ症例について, 臨床実践例を殖やし, そこから得られる細かい生体情報を集積すること で解答の系口を诚むことが必要であろう。

\section{IV 結 論}

何らかの基礎疾患をもつ泠え症21例を対象とし て銊炎治療を行った結果，(1)有効率は55.9\%で, 冷えの改善とともに随伴症状も緩解した。(2)冷之 症は, 愁訴と一致した身体部位に皮膚温の低下が 認められた。(3)鍼尒刺激は, 末梢循環動態に強い 影響を及ぼすことから，鍼灭治療は自覚的な冷え の改善に対し有効な治療手段の一つと言之る。な お今後は手足の冷えに対する鍼炎治療の臨床的効 果について，症例を集めながら，基礎疾患ごとの 比較検討を行なっていくつもりである。 


\section{参考文献}

1) 国分忠雄ほか：冷之症, 主婦と生活社, (1977).

2) 筒井末春ほか：冷之症と不定愁訴症候群, 日本 医事新報 $2925 ; 131$. (1980)

3）田中昭三ほか：冷え症, 医道の日本 $432 ; 33$ 54. (1980)

4）川名律子ほか：冷之症に対する鍼炎治療, 全日 本銊炎学会誌 36(3);203. (1986)

5）川名律子ほか：冷え症に対する銊炎治療 (II), 全日本鍼炎学会誌 $37(3) ; 198$.(1987)

6) 富家宗雄: 皮䖉温分布の季節変動に関する研究, 日温気物医誌 18(3);175 200. (1954)

7）渡辺ミチほか：Thermographyによる皮膚温測 定, 文化女子大紀要 7;157 164. (1976)

8）松田光司：健康成人男性の赤外サーモグラフィ 所見, 日皮会誌 $94(3) ; 245 ２ 59$. (1984)
9）鈴木正夫ほか：サーモグラフィによる健康成人 女性皮膚温の研究, 日温気物医誌 48(2);86 98. (1985)

10）丹沢章八：片麻瘴のリハビリテーションにおけ る鍼治療, 総合リハビリテーション 6(11);823 ～829. (1978)

11）丹沢章八：片麻舫の銊治療, 自律神経雑誌 26 $(3 \cdot 4) ; 128 \sim 135$. (1980)

12) Shohhachi Tanzawa: Acupuncture therapy in hemiplegic patients, Proceedings of the joint Japan-China Stroke Conference held in October of 1986 in Hirosaki and Tokyo, 137 $\sim 153$ : 1986.

（干243-01 神奈川県厚木市七沢1304 七沢リハビリテーション病院東洋医学科)

\title{
A Clinical Study of Acupuncture and Moxibustion for the Hypersensitivity to Cold
}

\author{
Kouzou Nemoto, Mamoru Mizukami and Shohhachi Tanzawa \\ Department of Oriental Medicine, Nanasawa Rehabilitation Hospital-Comprehensive \\ Stroke Center
}

We conducted acupuncture and moxibustion treatment to 21 patients with cold sensitivenees. They also had some sort of basal disorder and mainly claimed of coldness in the hands and feet. We compared the subjective and objective findings of the first visit and the tenth treatment.

Following were the results : 1) Along with $55.9 \%$ effectiveness of improvement in hand and feet coldness on a subjective basis, concomitant symptoms were also reduced. 2) Generally, those with cold sensitiveness have a lower skin temperature from the crus to the podalgia compared to the healthy, and we have also found that the parts of the body where the patient claimed had coldness indicated lower temperature. 3) Acupuncture and moxibustion stimulus has a strong impact on the peripheral circulation flow.

Thus the acupuncture and moxibustion treatment can be considered as one of the effective methods in relieving the subjective symptoms of cold sensitiveness. 